\title{
Rozhovor s Pavlem Maternou
}

Interview with Pavel Materna

\section{Josef Petrželka}

Pro celkově třetí rozhovor pro Studia philosophica jsem si zajel na Oddělení logiky Filosofického ústavu AV ČR v Praze, kde působí dlouholetý člen brněnské Katedry filozofie ${ }^{1}$ a aktuálně její emeritní profesor Pavel Materna. V rozhovoru zazněly ${ }^{2}$ opět otázky jak filosofické (a tentokrát i otázky takř́ikajíc „logické“), tak i osobnější. ${ }^{3}$ Poslouchat Pavlovy odpovědi a jeho vyprávění mi činilo velké potěšení, které se mi doufám podaří zprostředkovat i čtenářům.

Pavel Materna (*21. 4. 1930) vystudoval filosofii a psychologii na Univerzitě Karlově, záhy však přešel do své životní oblasti - logiky. Na brněnské Katedře filozofie působil poprvé v letech 1965-77. Protože mu však v době normalizace bylo zakázáno vyučovat i publikovat, odešel do Prahy do projektového ústavu PÚDIS. Od r. 1990 působí na Akademii věd ČR, od r. 1991 pak také opět i na naší katedře. Jak je zřejmé z data narození, Pavel Materna oslavil mezi pořízením rozhovoru a jeho vydáním krásné 90 . narozeniny. ${ }^{4}$

1 Slovo „filosofie“ a slova odvozená píšu jako antikář s „s“, pouze v oficiálních názvech a označeních (katedry, fakulty...) respektuji případné „z“.

2 Zazněly opět „živě“, byly i tentokrát zaznamenány v podobě zvukového záznamu, který byl následně - pro změnu bez pomoci umělé inteligence - zpracován do předkládané podoby.

3 Několik otázek dodala kolegyně Hana Rehulková - jsou to samozřejmě ty nejzajímavější otázky. Tímto jí za ně děkuji.

4 Shodou okolností jsme právě v ten den telefo-
Jménem redakce i brněnské Katedry filozofie Pavlovi gratuluji a přeji mnoho sil do dalších badatelských počinů!

\section{Spouštím nahrávání...}

M: Ted' už bych se měl hlídat, co říkám, ne?

P: Já ti to potom pošlu ke kontrole, až to zpracuji do psaného textu.

M: To má vyjít v prř́štím roce v tom vašem časopise.

P: Ano, mělo by to být po těch tvých velkých narozeninách, to číslo 1/2020 vyjde asi v červnu.

M: Doufám, že se to nebude muset měnit na nekrolog, nevím, nevím.

P: To určitě ne, vypadáš pořád dobře.

M: To klamu tělem.

P: V tom případě klameš velmi dobře. Moc děkuji, že jsi souhlasil s tímto rozhovorem. V předchozích rozhovorech jsem začínal otázkou ,jak jste se dostali k filosofii?" Ale protože ty jsi filosof a logik, tak by mne nejprve zajímalo, jaký je podle tebe vztah filosofie a logiky. Až potom se tě zeptám, jak ses k nim dostal.

\section{Jaký je vztah filosofie a logiky?}

M: To je dnes strašně složité, protože filosofie se roztříśtila na mnoho různých

nicky - jak jinak v době karantény - probírali závěrečné úpravy textu. 
směrů a logika se bohužel taky nestala jednotnou, takže rozštěpení obou je takové, že těžko říct, jaký je vztah filosofie a logiky. Já mohu říct, že třeba vztah logiky a parakonzistentní logiky, což je také filosofie, je velmi špatný, protože parakonzistentní logiky připouštějí bohužel kontradikci. Ti autoři píšou docela zajímavě a vtipně, ale filosoficky to nelze přijmout. Ale když tohle řeknu, tak vstane jiný filosof a řekne, že on by to přijal. Natolik je filosofie roztř́ístěná. Rozeznáváme dnes filosofii kontinentální a analytickou. To „kontinentální“ je naprosto nepřesné, protože mnoho analytických filosofü je právě v Evropě. Ale má se tím na mysli především francouzská filosofie, která je taková - no, dá se to těžko charakterizovat. Ta analytická filosofie má jednu výhodu, že se snaží vyjadřovat myšlenky jasně. Myslím, že kdyby se mělo definovat, co je analytická filosofie, tak to bude těžké, protože ona je taky roztř̌šstěná, ale ta schopnost vyjadřovat se přesně, srozumitelně, která vypadá jako samozřejmá, $\mathrm{k}$ ní patří, zatímco pro řadu jiných filosofií není zdaleka určující.

To je ten starý problém, že analytičtí filosofové např́klad s oblibou ř́kají - tak mi vysvětlete, co vlastně ten Heidegger ř́ká. Jednou jsem to zažil, že jsme se s někým snažili dopracovat $\mathrm{k}$ tomu, abychom rozuměli Sein und Zeit. Skončilo to bídně, protože jsme se - já a Tichý - velmi často museli ptát - a co asi rozumíte tímhle. A odpovědi nás neuspokojily - to se prý nemůžeme ptát, protože to prý pochopíme, až to celé nějakým zpưsobem strávíme.

To jsem se dostal moc daleko, ta jednoduchá otázka byla na vztah filosofie a lo- giky. Měly by si spolu rozumět. Filosofie by měla respektovat některé zásadní věci, které nám ř́íká logika, klasická logika.

Druhá věc je, že je zde filosofická logika a matematická logika a ty dvě si také úplně nerozumí. Já dělám tu filosofickou logiku, konkrétně systém transparentní intenzionální logiky Tichého, a tam si můžeme rozumět a $v$ tom jsem doufám v Brně zanechal nějakou stopu (a nechal jsem tam Jiřího Raclavského, který se stal mým nástupcem). Ale když se bavíme s matematickými logiky, s př́sně matematickými logiky, tak spoustě věcí nemůžeme rozumět, protože předpokládají složité algebraické prvky. Oplácíme jim to takto: Totiž, když matematická logika jako formální logika vytváŕí nějaký systém, tak vytváří nějaký umělý jazyk a ten případně pak interpretuje. A to právě u Tichého neznáme, tam syntaxi a sémantiku nerozlišíme. Tam se totiž nejprve provede logická analýza výrazů přirozeného jazyka. To je něco dřive nevídaného. Jiná věc je, že to dosud není př́liš přijímáno, tento systém tedy pro většinu logiků není př́liš atraktivní.

\section{Jaká byla tvoje cesta $\mathrm{k}$ filosofii a logice?}

P: Dobře, tak když se ted' objasnil vztah filosofie a logiky, jaká byla tvá cesta $\mathrm{k}$ nim?

M: Trošku složitá. Já jsem maturoval tuším v devětačtyřicátém, můj táta byl středoškolský kantor, strašně dobrý, matematika, filosofie a fyzika - ideální kombinace. Začal mne zasvěcovat do tehdejší začínající moderní logiky. Byli jsme izolovaní, do zahraničí jsme nemohli, takže jsme nevěděli, co se v logice děje. Můj 
táta patřil mezi propagátory moderní logiky, dokonce o tom něco napsal - a tak bylo jasné, že bych měl dělat něco s logikou. A také jsem měl zájem o filosofii, takže jsem šel na filosofickou fakultu a tam jsem měl jako první kombinaci filosofii a ruštinu. Mimochodem ruštinu jsem měl velmi rád a dodnes ji mám velmi rád. Tu kombinaci jsem pak změnil na filosofii a psychologii. Tam jsem ještě zažil velmi dobré, světové kantory psychologie, než je vyhodili.

A mezitím se začala formovat logika, byl tam prof. Zich. Když jsem končil studia, tak jsem nastoupil jako aspirant na oddělení logiky. A to byla ta stará garda, tam byla známá jména jako Mleziva nebo Jauris a později se $\mathrm{k}$ nim připojil Tichý. Do této skupiny lidí jsem tedy nastoupil.

Ale nebylo to ono. Mnoho jsem toho neudělal, ten pražský pobyt nebyl dobrý, nemohl jsem něco nabídnout a něco se naučit, psal jsem nějaké pseudočlánky, se kterými nejsem spokojený, nějakou populární knížku jsem napsal, jako třeba Umíte logicky myslet?, ${ }^{5} \mathrm{v}$ podstatě nic nového.

Co ze mne udělalo logika, bylo právě to, že jsem se seznámil s Tichým, když tam ještě byl, a když pak odjel do exilu na Nový Zéland, tak jsme si korespondovali. Strašně si nadávám za to, že jsem tu korespondenci nezachoval. A s Tichým jsem se dozvěděl věci, které jsem se chtěl dozvědět. To pokládám za začátek mé skutečné logické činnosti.

Jakmile jsem viděl, že ta Tichého logika je spjata s filosofickými předpoklady, tak bylo jasné, co budu dělat. Několik let

$5 \quad$ Státní pedagogické nakladatelství, 1968 (pozn. red.). jsem proflákal, když jsem dělal takové blbosti... Abych si odbyl vojenskou službu - to byla pro mne hrůza, tak mne přijali na vojenskou politickou akademii a tam jsem přednášel filosofii. To byla $\mathrm{v}$ podstatě ztráta času. Pak jsem měl nějaké problémy, dva roky jsem dělal brigádu na Kladně. A pak jsem jel jednou služebně z Nakladatelství technické literatury do Brna a tam jsem znal profesora Macháčka, tak jsem mu jen tak zavolal a on „tak co děláš“, já „no to je tak“, a on „přijd', my tady potřebujeme logika“. Tak jsem zajásal a za půl roku jsem byl v Brně.

Tam jsem začal přednášet takovým tím formalistickým způsobem, nadělal jsem tam spoustu teorémů, důkazů a tak dál, velmi formálně.

A taky jsem napsal skripta, ale později jsem zjistil, že studenti to vůbec nechápali. To beru jako svůj neúspěch a jako že já jsem se něco naučil, ne oni - naučil jsem se trochu přednášet logiku. A tehdy jsem se tam dostal ke skriptům Tichého, která už byla začátkem té jeho koncepce transparentní intenzionální logiky. Tak jsem na fakultě zakázal užívat moje skripta a doporučil jsem skripta Tichého.

Jezdil jsem pak na konference do zahraničí, v Americe jsem byl pozván k prof. Bealerovi, to byl velice zajímavý člověk, i když nedělal přesně to, co já. Když jsem přiletěl do Ameriky, čekal tam na mne nějaký jeho doktorand, ten mne zavezl k Bealerovi a první otázka byla ne „jaká byla cesta?“, ale ,je trivializace jako konstrukce jednoduchá nebo složená?“. Tam se mi líbilo, tam to bylo zajímavé.

Měl jsem přednášky na nějakých konferencích, mohl jsem třeba přednášet v Itálii, to bylo opravdu dobré. Měl jsem 
zvláštní, pestré zkušenosti a život a nemůžu říct, že se mohu chlubit vším, co jsem udělal. Něco, čeho si mohu skutečně vážit, jsem napsal, až když mi bylo šedesát. Skutečně.

\section{Jaký je tvůj vztah k psychologii, kterou jsi také studoval?}

P: Já se potom ještě vrátím k naší katedře, ale ted' bych chtěl udělat takový krok stranou. Ty jsi studoval i psychologii - potom ses k ní už nijak nedostal, už ti nebyla blízká?

M: Když jsem byl ještě v Brně, tak jednu dobu tam byly povinné přednášky logiky pro psychology, tak s některými jsem navázal celkem dobré vztahy, ale nic zvláštního z toho nevzešlo. Psychologie má problémy, které by se daly analyzovat $\mathrm{z}$ hlediska logiky, ale nedostal jsem se k tomu, abych to nějakým způsobem aplikoval. Některé proudy v psychologii byly napojeny na zrod kybernetiky a to mne zajímalo.

Ovšem důsledně jsem bojoval s psychologismem v logice, to dělal už Frege. Pokusy řešit logické problémy psychologicky už byly poraženy, ale ten psychologismus se občas v různých podobách vrací. V logice či v sémiotice se rozlišovala syntaxe, sémantika a pragmatika. V té Tichého logice jsem zjistil, že tam se dá syntaxe a sémantika spojit jako analýza přirozeného jazyka. Ale pragmatika není z hlediska logiky zajímavá.

P: Psychologie se snaží být experimentální a vědecká a snaží se pomocí různých přístrojových měření - EKG apod. - vyjadřovat i k různým filosofickým, estetickým a etickým otázkám. Je to přijatelné?
M: Jestli to není spíše hřích proti filosofii... Filosofové přijdou s nějakým problémem, třeba svoboda vưle, a samozřejmě se přihrnou psychologové. Jde o to, jestli to není vnucování metod vlastních psychologii něčemu, co psycholog nemůže zodpovědět. Do toho se nepletu, ale rozeznám, co je filosofická argumentace a co specificky psychologická argumentace. S psychologismem sice bojuji, ale společná témata mezi filosofií a psychologií existují. Ale nemyslím, že psychologie může cokoli říct $\mathrm{k}$ takovým problémům, jako je třeba otázka zítřejší bitvy u Aristotela. Respektive může něco říct, ale to už bude trochu jiný problém.

\section{Jak se vyvíjela česká logika?}

P: Ty jsi už představil své dlouholeté působení na poli logiky, velmi dlouholeté - které ještě samozřejmě nekončí, a mne by zajímalo, jestli se za toto období dají vysledovat ve vývoji české logiky nějaké výrazné proměny.

M: My jsme nikdy neměli logickou tradici. Byl tam můj táta, pak tam byl Zich, to je zvláštní kapitola, a potom tam byli nějací matematici.

Česká matematická logika si získala určité světové jméno. Před pár lety zemřel Petr Hájek, to byl dobrý moderní logik, který dělal fuzzy logiku. Dále vyšly dvě velké knihy matematické logiky, ta matematická logika drží krok se světem.

Pokud máš na mysli logiku obecně, tak se hodně namluvilo o tom, jestli vůbec existuje filosofická logika, jestli to vůbec je logika, protože nepracuje tak, že by začala jazykem a axiomy. Jako jediný pokrok vidím to, že se tady vytvořila 
skutečně pozoruhodná skupina, která filosofickou logiku začala dělat, to jsou ti Slováci - Gahér a celá ta jeho škola, mladí lidé, kteří už mají celkem dobré jméno a mají články v renomovaných světových logických časopisech. Především však jde o Marii Duží, která se stala nejlepší a nejaktivnější specialistkou na TIL a je po celém světě frekventovaně zvána jako přednášející. Byla také hlavní autorkou naší náročné práce Procedural Semantics for $\mathrm{Hy}$ perintensional Logic. ${ }^{6}$ Podařila se mi jedna věc, že když přijel do Brna postdoktorand z Dánska, Bjørn Jespersen - on měl takovou cestu na postdoktorátu po Evropě - mně se podařilo předělat ho na TIL. Ted' dostal místo na fakultě v Utrechtu. Tady v Praze jsem osamocený, protože tu transparentní intenzionální logiku nedělá nikdo kromě nějakých mladých lidí.

Problém je v tom, že kdybys chtěl dnes dostat v Evropě placené místo na univerzitě v oboru logika, tak to skoro nenajdeš. Ta matematická logika, ta je na matematických ústavech.

Čili vývoj u nás šel kupředu v té matematické logice, a pokud jde o tu filosofickou logiku, pak bych neřekl, že je tu nějaký velký vývoj, ale je tu ta skupina lidí, včetně toho Bjørna Jespersena, který je v tom Utrechtu, ta dělá takové věci, že si toho venku všimnou.

Tady byla totiž taková zvláštní situace. Všechny Tichého spisy byly sice uveřejněny, až na nějakou výjimku, ale nemělo to ohlas, byl jistým způsobem ignorován. Ve Stanford Encyclopedia of Philosophy je

6 DUŽÍ, Marie - JESPERSEN, Bjorn Thoring F. MATERNA, Pavel. Procedural Semantics for Hyperintensional Logic. First edition. Berlin: Springer Verlag, 2010. explicitně řečeno, že je škoda, že TILka nebyla dostatečně popularizována, a uvádějí tam, v čem je nová. ${ }^{7}$ Ovšem jestli je to něco, co bude mít trvalejší vliv, to se pozná až za pár let. Není to zatím nějaký bouřlivý př́liv, ale chytlo se to. Když se dnes zeptáš v zahraničí na transparentní intenzionální logiku, tak už to znají. To neznamená, že to dělají podle toho. Tam když člověk řekne, že něco dělá Tichý, tak - aha, Montague. Montague byl dobrý, ale zdaleka nedosahoval toho, co dělal Tichý.

\section{Je logika (a filosofie) jen teorií, nebo má i praktický dopad?}

P: Ted' zase otázka trochu stranou. Je logika i filosofie vůbec záležitostí čistě teoretického bádání, a tedy je to zajímavé jen pro teoretiky, anebo to má i nějaký širší praktický dopad?

M: Záleží na tom, co bereš jako praktický dopad. Protože když řekneš praktický dopad třeba u matematiky, tak tam máš

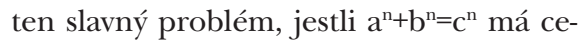
ločíselné řešení pro $\mathrm{n}>2$, který byl konečně po několika staletích vyřešen. A jaký praktický dopad to mělo, že?

Jedna možná odpověd' je, že praktické dopady logiky jsou v tom, že se na tom učí praktikové. Praktičtí logikové jsou možní proto, že si nastudují teoretickou logiku. To je tedy první a hlavní účel. Jinak myslím, že uznáš, že praktický dopad

7 Viz FITTING, Melvin. Intensional Logic. In Zalta, E. (ed.). The Stanford Encyclopedia of Philosophy [online]. Spring 2020 Edition [cit. 8. 5. 2020]. Dostupné z: <https://plato.stanford. edu/archives/spr2020/entries/logic-intensional/>, konkrétně část 2.5 Montague, Tichý, Bressan, and Gallin (pozn. red.). 
toho, co dělám nebo co dělá ta Marie, je řešení problémů z lingvistiky, které není možné řešit bez logiky. Tedy praktický dopad může být i v tom, že to má význam pro jiné teorie.

Je tady velké pole problémů, které ta starší logika neřešila. Takový jednoduchoučký příklad: Když řekneš „3+2“ tj. pět, že, a pak když řekneš „Karel řeší 3+2“, tak nemůžeš říct „Karel řeší pět“, to je nesmysl. Jak z toho ven? Žádná logika kromě TILky to nedovede. Př́padně to obejde a začne to řešit $\mathrm{v}$ metalogice nad přirozeným jazykem.

Nebo problém tzv. paradoxů (mimochodem, těm se věnoval také Jiří Raclavský) - je to studium čistě teoretické? Není, dopad je $\mathrm{v}$ tom, že se přitom řeší momenty, které by jinak řešeny nebyly nebo byly řešeny špatně. Například to, co by se řešilo tím vybočením $\mathrm{z}$ logiky, se ted' řeší $\mathrm{v}$ rámci logiky. To je přímo mohutný dopad, že se to dá všechno udělat logicky. Víc tě asi neuspokojím, protože ta logika je sama o sobě ryze teorií.

\section{Lze analytickou filosofii chápat jako určitý projev postoje člověka ke světu?}

P: Já budu mít ještě jednu doplňující otázku, když využiji toho, čím se zase zabývám já. $\mathrm{V}$ antice byla filosofie velmi často jakýmsi postojem či zkoumáním postoje člověka ke světu, ke skutečnosti, k životu.

M: Což je filosofický problém.

P: A mne by zajímalo, jestli je možné něco takového říct o analytické filosofii, která zkoumá jazyk a jazyk je přece jedním z nejdůležitějších projevů postoje člověk ke světu. Lze tedy říct, že analytická filosofie je právě v tom také projevem postoje člověka ke světu?
M: To jistě, svým způsobem ano, protože analytická filosofie je taky filosofie a filosofie je dána tím vztahem ke světu. Ta takzvaná kontinentální filosofie, nejlepší př́ílad je Heidegger, což byl velký filosof, o té se říká, že je postojem člověka ke světu. Což je jedna z takových polodefinic filosofie.

A řekl bych, že to ta analytická filosofie taky je, tím, co řeší a jak to řeší. Analytická filosofie se věnuje tomu, jak rozumět světu na základě jazyka, a to ti třeba může odhalit pseudofilosofické problémy - tady si dovedu představit aplikaci analytické filosofie přímo na životní otázky. Protože tam, kde ta kontinentální filosofie něco říká jazykem, kterému bude nefilosof těžko rozumět, tam se od analytické filosofie bude očekávat, že vysvětlí nefilosofovi, co se tím myslí. Tam by dokonce mohla být - někdy myslím i je - spolupráce mezi tou kontinentální a analytickou filosofií.

\section{Jakým způsobem existuje hudba?}

P: Další otázka se týká hudby. Ty máš hudbu rád, hudbu sám provozuješ - jakým způsobem existuje hudba?

M: Jako abstrakta. Je taková hra ano ne. Něco si myslíš a ten druhý hádá, co to je. A myslís si třeba Devátou symfonii Beethovenovu. A ted' první otázka toho hádajícího bude - ,je to konkrétní?“. A ty musîs říct, že ne. Když totiž máš definici konkrétního a abstraktního, tak se na tom vyřádíš, když jde o hudbu. Rozeznáš přitom skladbu - ta je abstraktní, pak její provedení, její zápis a tak dál. A pak budeš mít nějaký úsek, u kterého budeš přímo „řičet nadšením“, ale „řičet nadšením“ není žádný zvláštní pojem - to je otázka estetiky. A čím víc hudbu proží- 
vám, tím více se zdržuji pokusu ji teoreticky uchopit.

$\mathrm{P}$ : Jestli tomu dobře rozumím, takovým abstraktním způsobem existuje nejen ta Beethovenova Devátá, ale i méně známé skladby?

M: Samozřejmě.

P: I skladby, které ještě nebyly napsány?

M: Když nebyla napsána, tak ta skladba nemohla zaznít, že, ale pokud...

P: Protože to, co nebylo napsáno, je určitě nějaká teoretická kombinace not, tím pádem vlastně i čísel.

M: A pak je objevována.

P: Takže v tomto smyslu -

M: Ano, tak realismus chápe hudbu, tak tomu já rozumím. Můžeš se na to zeptat Rostislava Niederleho v Brně, ten o tom napsal mnoho věcí. Oba jsme realisté. Skladatel dělá to, co vědec, když objevuje zákony. Skladatel objevuje skladby. Kdyby neměl co objevovat, tak by to měl těžké. V tomto smyslu existují skladby, které nejenže nebyly nikdy provedeny, ale ani nebudou nikdy provedeny. Pokud je to skutečně objevováno, pak musíš držet to, že je to abstraktní, nikoli konkrétní. Není to vázáno na časoprostor. Ale když to zazní, je to provedeno, tak to existuje, ale není to táž existence, jako když je to v notovém zápise. On to Rosta dělá na výtvarném umění, ale dělat to na hudbě by také stálo za to - a to bych nazval filosofickou prací. Protože co je to estetika? Když to nebudeš brát jako řešení nějakého filosofického problému, tak nevím, co by to bylo. A přitom je to rozvinutý obor.

Ale zajímavé je, že když se řekne „teorie umění", většinou se tím myslí výtvarné umění. A přitom v té hudbě je nejvíce podnětů.

\section{Jaké jsou tvé vzpomínky na brněnskou ka- tedru filozofie?}

P: Děkuji. Poslední otázka. Jaké jsou tvé vzpomínky na brněnskou katedru filozofie, na které jsi strávil desítky let? A je podle tebe ta katedra něčím specifická?

M: To jsou takové jednoduché otázky... Já jsem tam byl dost dlouho, že ano?

P: Ano.

M: Takže jsem ji zažil v jejím vývoji, abych tak řekl. Zažil jsem ještě Macháčka. To by byla speciální studie - člověk Macháček.

Čeho si vážím, že ta katedra žila takovým dobrým vzájemným životem. Takže jsem se s nimi se všemi dost sžil, třeba Karel Hlavoň a Jirka Gabriel - to byl krásný párek! Od každého jsem něco dostal, s někým jsem se pohádal, ale nikdy jsme se nepohádali nějak, aby byl konflikt, nikdy to nebylo hněvivé. Toho jsem si vážil i v té zlé době normalizace, tam se to ukázalo. Chci říct, že ta katedra se vždycky ukázala jako taková lidská. Bylo to až dojemné, když to člověk srovná... Já jsem byl vyloučený - ale na katedře to vymysleli tak, abych tam zůstal, že jsem tam pak ilegálně přednášel o Montaguem, a tam chodili i komunisti, to byla sranda. To bylo dobré.

Taková ta tolerantnost měla krásné rysy, že oni chtěli, aby se ti lidi neničili, co mohli, to pro ně udělali, ovšem platili za to určitou cenu. Ale jinak ty kulturní výlety, to bylo krásné.

Jen jsem nemohl dělat, co jsem chtěl, tenkrát když člověk dělal filosofii, tak to byl vždycky problém. Ale když jsem měl zákaz publikací a nemohl jsem potom učit, tak se to dělalo tak nějak pololegálně. 
Byla tam spolupráce s lingvisty, napří- TILka, lingvistické problémy řešené séklad Karel Pala. A tehdy byl ještě naži- manticko-syntakticko-pragmaticky, to se vu Aleš Svoboda. Vytvořili jsme jakousi mi celkem líbilo.

třísložkovou koncepci - to ještě nebyla P: Já moc děkuji, Pavle. užity na základě smluvní licence nebo výjimky či omezení přislušných práv. 